\title{
Focal fibrous hyperplasia beneath the tongue -A rare case report
}

\begin{abstract}
:
Focal fibrous hyperplasia is a slow growing connective tissue tumor that frequently occurs in different anatomic sites of the oral cavity. The present case report describes the occurrence of this lesion on the ventral surface of the tongue which is hitherto least reported intraoral site, in a 11 year old male patient, which was successfully excised.
\end{abstract}

Key-words:Focal fibrous hyperplasia, Benign tumor, Tongue, Histopathology

\section{Introduction:}

The focal fibrous hyperplasia (FFH), also known as irritation fibroma, fibromatoses fibroma or oral fibroma was first reported in 1846 by Tomes.[1,2] It is mainly caused due to irritation present in the oral cavity like trauma from sharp teeth, plaque, calculus and overhanging margins of restorations or dental appliances.[3,4] It is a reactive, inflammatory and hyperplastic benign tumour of the connective tissue, typically well demarcated and can vary in its size, from a few millimetre to few centimeters.[5] It is almost always a slow growing lesion that occurs at any age, females being more likely to be affected than males.[6]

FFH may occur at varied intraoral sites, the most common sites being the gingiva and occlusal line of the buccal mucosa, the other sites being the lower lip, palate, and the tongue.[6,7] A survey of literature on the occurrence of FFH revealed that though its site distribution in the oral cavity is variable, involvement of tongue is very limited.[8-12]

This case report describes the occurrence of FFH on the under surface of the tongue of a 11 year old male child which was successfully managed by excisional biopsy.

\begin{tabular}{|l|l|}
\hline \multicolumn{3}{|c|}{ Access this article online } \\
\hline \multirow{2}{*}{$\begin{array}{l}\text { Website: } \\
\text { www.ujds.in }\end{array}$} & Quick Response Code \\
\hline $\begin{array}{l}\text { DOI: } \\
\text { https://doi.org/10.21276/ujds.2020.6.3.21 }\end{array}$ & \\
\hline
\end{tabular}

\section{Case History:}

Eleven year old male child reported to the with complaint of a growth under the tongue near its tip for the past one year [Figure 1]. After recording detailed case history of the patient, it was revealed that the lesion was slow growing, painless with almost no remarkable change in its size after its appearance. On examination, a solitary, pedunculated swelling was found on the ventral surface of tongue in between the frenulum and its tip which was firm, non- tender and mobile on palpation. The size of the growth was approximately $0.9 \times 0.7 \mathrm{~cm}$ which was non pulsating and non-compressive on palpation. The colour of the lesion was reddish pink. The lesion was non inflammatory and without any ulceration present over it. No lymph node involvement was seen in sub-mental or sub-

\footnotetext{
${ }^{1}$ RAZI, M. A., ${ }^{2}$ DEBNATH, S., ${ }^{3}$ KIRTANIYA, B. C., ${ }^{4}$ SEEMA QAMAR.

${ }^{1,2}$ Department of Periodontology, Hazaribag College of Dental Sciences \& Hospital, Hazaribag, Jharkhand ${ }^{3}$ Department of Pedodontics and Preventive Dentistry, Mithila Minority Dental College and Hospital, Darbhanga. ${ }^{4}$ Department of Pedodontics and Preventive Dentistry, Hazaribag College of Dental Sciences and Hospital, Demotand, Hazaribag Jharkhand.
}

Address for Corresponding : Mohammed Ahsan Razi Department of Periodontology, Hazaribag College of Dental Sciences and Hospital, Hazaribag, Jharkhand.

Email : mahsan0708@gmail.com

Received : 30 Nov. 2020, Published : 31 Dec. 2020 
mandibular regions. Radiographic examination did not show any evidence of calcification inside the lesion. It also did not show calculus into the salivary gland ducts. Based upon the clinical presentation of the lesion, the differential diagnosis of fibroma and fibrous hyperplasia was made.

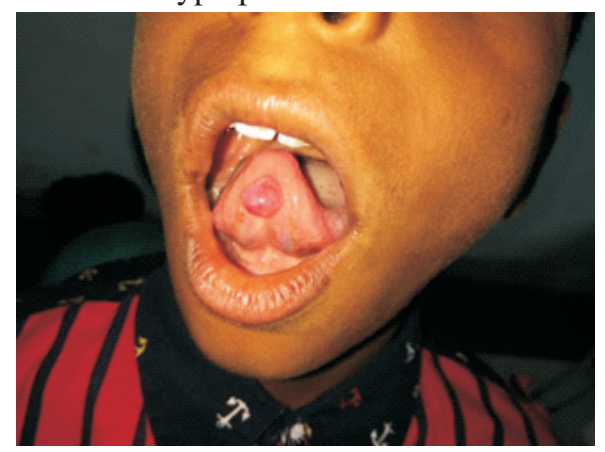

Figure. 1: Pre-operative - Focal fibrous hyperplasia showing a firm, non-tender soft tissue growth on the ventral surface of tongue

Considering the size and location of the lesion surgical excision of the lesion was planned and the treatment and outcome of the surgery was well explained to the patient and his accompanying father. Subject being minor, the consent for surgery was obtained from his father. Prior to excision of the lesion, a complete haematological investigation of the patient was done. The bleeding time, clotting time, haemoglobin percentage, and total and differential leukocyte counts were within normal limits.

Excisional biopsy was executed using scalpel blade under infiltration of local anaesthesia with adrenaline $(1: 100,000)$ [Figure 2].

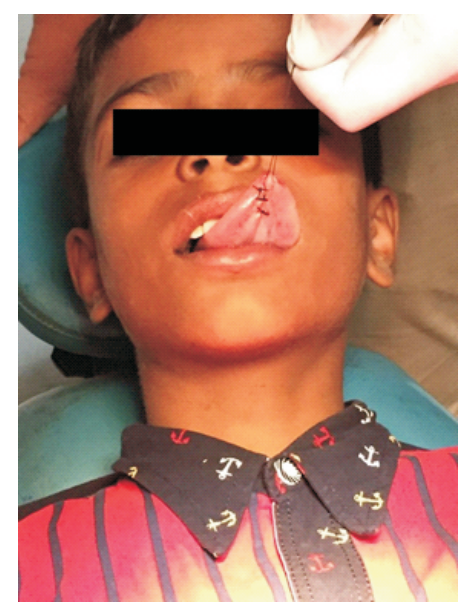

Figure. 2 Immediate post-operative - After surgical excision of focal fibrous hyperplasia.

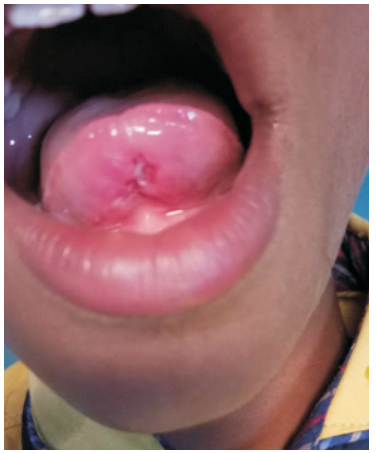

Figure. 3 Post-operative healing after 7 days of excision of lesion.

The excised specimen was fixed in $10 \%$ formalin and was sent to the department of oral pathology for histo-pathological analysis. Follow up examination after a week was done to confirm uneventful healing. [Fig. 3]

The histo-pathological analysis of the excised lesion showed hyperplastic parakeratinized stratified squamous epithelium with acanthosis of stratum spinosum. The underlying connective tissue stroma exhibited bundles of collagen fibres arranged haphazardly with plenty of fibroblasts. There was evidence of diffuse chronic inflammatory infiltrate. [Fig. 4 and Fig. 5] These features confirmed that the excised lesion was focal fibrous hyperplasia.

\section{Discussion:}

Focal fibrous hyperplasia, being the most common benign soft tissue growth in the oral cavity have been studied by a number of workers.[5,6,8-10,14-19] It is most common in 3, 4 and 5 decade of life but may occur at any age.[6] Studies carried out on different sets of human population, including Indians have revealed that the most frequently involved intraoral anatomic sites of FFH were the gingiva followed by buccal mucosa and palate.[8-10,13,15]

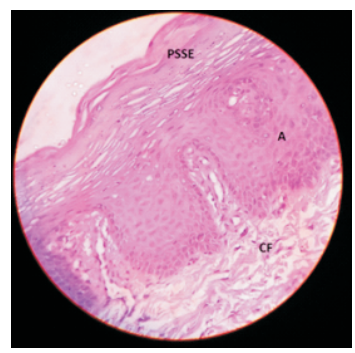

Figure 4: H \& E stained histolgical section (10X) showing hyperplastic parakeratinized stratified squamous epithelium (PSSE) with acanthosis (A) of stratum spinosum. CFBundles of collagen fibres.

Although the site distribution of FFH in the oral cavity is 
variable, its occurrence on the tongue appears to be relatively one of the lowest, and the under surface of the tongue being the least affected region.[8,10-12] In the present case, interestingly, the FFH was located on the inferior surface of the tongue in between its tip and the frenulum which appears to be a least common site.[15] Furthermore, this lesion is generally smooth surfaced, asymptomatic, soft and generally sessile nodule. These characteristics were also found in the present case except that the FFH was with a short peduncle as also reported in some cases.[14,20]

Histologically, the FFH contains fibrous connective tissue containing fibroblasts, a few chronic inflammatory cells and surrounded by an atrophic parakeratinized squamous epithelium.In the present case, based on clinical presentation of the lesion and histo-pathological findings, a final diagnosis of FFH has been made. The similarity in clinical appearance of many types of localised reactive lesions in the oral cavity including FFH, pyogenic granuloma, peripheral ossifying fibroma, peripheral giant cell granuloma etc., pose a challenge in their definitive diagnosis and hence it should be done carefully.[14-22]

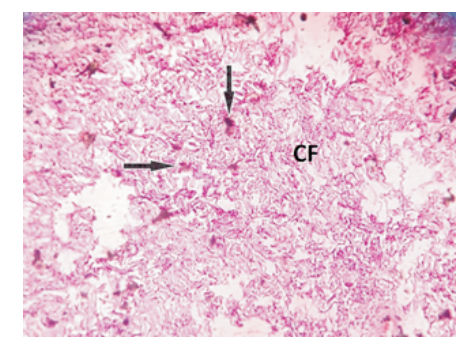

Figure 5: H \& E stained histolgical section (40X) showing dense collagen fibre bundles (CF) with diffuse chronic inflammatory infiltrate (arrows).

\section{Conclusion:}

The FFH is a very frequent type of benign connective tissue growth involving different intraoral sites. The present case report describes the occurrence of this lesion at a relatively unusual site (under surface of the tongue) and its excisional biopsy in a 11 year old male child.

\section{Acknowledgements:}

Authors express their sincere thanks to the patient and his father who willingly participated in the study. Thanks are also due to Dr. Ankur Bhargava, Reader, Department of Oral Pathology, Hazaribag College of Dental Sciences and Hospital for histo-pathological report of the excised lesion.
We also extend our sincere thanks to Dr. M. Raziuddin, Vice Chancellor, R.G. University, Ramgarh, Jharkhand for critically going through the manuscript.

\section{References:}

1) Tomes J. A, Course of Lectures on Dental Physiology and Surgery. Am J Dent Sci. 1848;8:313-50.

2) Saurel L, Memoirs upon the tumors of the gums, known under the name epulis. Am J Dent Sc 1858;8:33-43,21231.

3. Bagde H, Waghmare A, Savitha B, Vhanmane P. Irritation fibroma - A case report. Int J Dent Clinics 2013;5:39-40.

4. Mathur LK, Bhalodi AP, Manohar B, Bhatia A, Rai N, Mathur A. Focal fibrous hyperplasia: a case report. Int J Dent Clinics 2010;2:56-7.

5. Lanjekar A, Kulkarni S, Akhade S, Sonule S, Rathod U. An Unusually Large Irritation Fibroma Associated with Gingiva of Lower Left Posterior Teeth Region. Case Reports in Dentistry 2016, Article ID 5202181, 4 pages, 2016.

6. Rajendran R. Benign and malignant tumors of the oral cavity. In: Rajendran R and Sivapathasundharam B, editors.Shafer's textbook of oral pathology,7th ed. New Delhi: Elsevier;2012.p.81-222.

7. Gonsalves WC, Chi AC, Neville BW. Common oral lesions: Part II. Masses and neoplasia. Am Fam Physician 2007;75:509-12.

8. Reddy V, Saxena S, Saxena S, Reddy M. Reactive hyperplastic lesions of the oral cavity: A ten year observational study on North Indian Population. J Clin Exp Dent 2012;4:136-40.

9. Hunasgi S, Koneru A, Vanishree M, Manvikar V, Patil AM, Gottipati H. Retrospective analysis of the clinical features of 530 cases of reactive lesions of oral cavity. J Adv Clin ResInsights 2014;1:1-6.

10. Patil SR, Maheshwari S, Khandelwal S, Wadhawan R, Somashekar SB, Deoghare B. Prevalence of reactive hyperplastic lesions of the gingiva in the Western Indian population. Journal of orofacial sciences 2014;6:41-5.

11. Kadeh H, Saravani S, Tajik M. Reactive hyperplastic lesions of the oral cavity. Iran Otorhinolaryngol2015;27:137-44.

12. Halim DS, Pohchi A,Yi PE. The Prevalence of Fibroma in OralMucosa Among Patient Attending USM Dental Clinic Year 2006-2010. The Indonesian JDent Res 2010;1:61-6.

13. Dutra KL, Longo L, Grando LJ, Rivero ER. Incidence of 
reactive hyperplastic lesions inthe oral cavity: a 10 year retrospective study in Santa Catarina, Brazil. Braz JOtorhinolaryngol. 2018.

14. Sangle VA, Pooja VK, Holani A, Shah N, Chaudhary M, Khanapure S. Reactivehyperplastic lesions of the oral cavity: A retrospective survey study and literature review.Indian J Dent Res 2018;29:61-6.

15. De Santana Santos T., Martins-Filho P. R., Piva M. R., de Souza Andrade E. S. Focal fibrous hyperplasia: a review of 193 cases. Journal of Oral \& Maxillofacial Pathology. 2014;18:86-9.

16. Alam MN, Chandrasekaran SC, Valiathan M. Fibroma of theGingiva: A Case Report of a 20 Year old Lesion. IJCD 2010;1:107-9.

17. Mathur LK, Bhalodi AP, Manohar B, Bhatia A, Rai N,Mathur A. Focal fibrous Hyperplasia: A case report: International Journal Of Dentalclinics 2010;2:56-7.

18. Vujhini SK, Reddy SE, Sudheer MVS, Katikaneni HK. Irritation fibroma of tongue: acase report. Int J Res Med Sci 2016;4:1272-3.

19. Zarei MR, Chamani G, Amanpoor S. Reactive hyperplasia of the oral cavity inKerman province, Iran: A review of 172 cases. Br J Oral MaxillofacSurg 2007;45:288-92.

20. Pardeshi KV, Mirchandani NM, Agrawal AA, Kale TM. Fibrous hyperplasia: Twocase reports. J Dent Lasers 2016;10:23-7.

21. Mishra MB, Bhishen KA, Mishra S. Peripheral ossifying fibroma. J Oral MaxillofacPathol. 2011;15:65-8

22. Katsikeris N, Kakarantza-Angelopoulou E, Angelopoulos AP. Peripheral giant cell granuloma. Clinicopathologic study of 224 new cases and review of 956 reported cases. Int J Oral Maxillofac Surg 1988;17:94-9. 